\title{
Effects of L-carnitine and/or maize distillers dried grains with solubles in diets of gestating and lactating sows on the intestinal barrier functions of their offspring
}

\author{
Bingdong Wei†, Shaoping Nie†, Qingwei Meng, Zhe Qu, Anshan Shan* and Zhihui Chen \\ Institute of Animal Nutrition, Northeast Agricultural University, Harbin 150030, People's Republic of China \\ (Submitted 10 September 2015 - Final revision received 8 April 2016 - Accepted 11 April 2016 - First published online 3 June 2016)
}

\section{Abstract}

The objective of this study was to investigate the effects of L-carnitine and/or maize distillers dried grains with solubles (DDGS) in diets of gestating and lactating sows on the intestinal barrier functions of their offspring. The experiment was designed as a $2 \times 2$ factorial with two dietary treatments (soyabean meal $v$. DDGS) and two L-carnitine levels $(0 v .100 \mathrm{mg} / \mathrm{kg}$ in gestating diets and $0 v .200 \mathrm{mg} / \mathrm{kg}$ in lactating diets). Sows (Landrace $\times$ Large White) with an average parity of 4.2 with similar body weight were randomly assigned to four groups of thirty each. Dietary supplementation with L-carnitine increased the total superoxide dismutase activity but decreased the concentration of malondialdehyde of the jejunal mucosa in newborn piglets and weaning piglets on day 21. Dietary supplementation with L-carnitine decreased the concentrations of IL-1 $\beta$, IL-12 and TNF- $\alpha$ in the jejunal mucosa of newborn piglets and decreased the concentrations of IL- 6 and TNF- $\alpha$ in the jejunal mucosa of weaning piglets on day 21 . There was an interaction between dietary treatment and $\mathrm{L}$-carnitine on the bacterial numbers of total eubacteria in the digesta of caecum in weaning piglets on day 21 . Bacterial numbers of total eubacteria in weaning piglets on day 21 were significantly increased by L-carnitine only in soyabean meal diet, but there was no significant effect of L-carnitine in DDGS-based diet. Dietary supplementation with L-carnitine increased the bacterial numbers of Lactobacillus spp. and bifidobacteria spp. in the digesta of caecum in weaning piglets on day 21. Dietary supplementation with L-carnitine in sows affected the expression of tight junction proteins (claudin 1, zonula occludens-1 (ZO-1) and occludin) in the jejunal mucosa of their offspring by increasing the expression of ZO-1 mRNA in the jejunal mucosa of newborn piglets, and by increasing the expression of ZO-1 and occludin mRNA in the jejunal mucosa of weaning piglets on day 21. In conclusion, dietary supplementation with L-carnitine in gestating and lactating sows had positive effects on intestinal barrier functions of newborn piglets and weaning piglets on day 21, but it did not have effects on intestinal barrier functions of growing-finishing pigs in the filial generation. There were no effects of dietary treatment of sows on intestinal barrier functions in their offspring.

Key words: L-Carnitine: Distillers dried grains with solubles: Intestine barrier: Sows: Offspring

Distillers dried grains with solubles (DDGS) is a by-product produced by dry-grind ethanol plants and has become a valuable low-cost feed ingredient for replacement of maize, soyabean meal and inorganic phosphate in diets of pigs. Sows are ideal candidates for diets containing DDGS because of its moderately high fibre content. DDGS contains approximately three times the concentrations of fat, protein, fibre and minerals compared with maize ${ }^{(1)}$, and many studies have indicated that supplementation of DDGS to sows during gestation and lactation had no negative effect on the sow and litter performance $^{(2-4)}$. However, maize DDGS contains approximately $10 \%$ maize oil $^{(5)}$, and the lipids in DDGS predominantly comprise PUFA, which are prone to preoxidation ${ }^{(6)}$. During drying, DDGS are heated at relatively high temperatures, potentially leading to the formation of secondary lipid oxidation products $^{(5)}$. Therefore, DDGS might be prone to significant lipid peroxidation. However, most studies have ignored the potential risk of oxidative stress upon the DDGS to the diet of sows and offspring.

L-Carnitine plays a key role in cell metabolism by regulating the mitochondrial transport of long-chain free fatty acids and the generation of ATP by $\beta$-oxidation ${ }^{(7)}$. Evidence indicated that dietary L-carnitine is beneficial to sows, by enhancing reproduction performance and milk production ${ }^{(8-10)}$. Furthermore, other studies have demonstrated that L-carnitine supplementation may enhance gastrointestinal protective ${ }^{(11,12)}$, antioxidant ${ }^{(13)}$, anti-inflammatory $^{(14)}$ and radioprotective ${ }^{(15)}$ properties.

In our previous study, we have found that the DDGS diet revealed negative effects on weights of piglets at birth and weaning, but it did not influence the number of total piglets,

Abbreviations: DDGS, distillers dried grains with solubles; GSH, reduced glutathione; MDA, malondialdehyde; SOD, superoxide dismutase; ZO-1, zonula occludens-1.

* Corresponding author: A. Shan, email asshan@neau.edu.cn

$\dagger$ These authors contributed equally to this work. 
piglets born alive and piglets at weaning, and sows treated with L-carnitine had higher birth weight and weaning weight regardless of sows' dietary treatments (soyabean meal $v$. DDGS). Furthermore, L-carnitine supplementation of sows causes also an increase of L-carnitine concentrations in milk and the carnitine status of their offspring. In addition, there are no published data on the effects of maternal dietary treatments and L-carnitine in sows on intestinal function of their offspring. Therefore, the aim of the present study is to evaluate the effect of dietary treatment and L-carnitine in gestating and lactating sows on the intestinal barrier functions of their offspring and the possible interaction between dietary treatment and L-carnitine on the intestinal barrier functions including antioxidant capacity, concentrations of cytokines, intestinal microbiota and tight junction mRNA expression of their offspring.

\section{Methods}

The DDGS used for the experiment was provided by Jilin Alcohol Company Limited. The DDGS was analysed for crude protein $(295.7 \mathrm{~g} / \mathrm{kg})$, crude fat $(100.4 \mathrm{~g} / \mathrm{kg})$, crude fibre $(71.3 \mathrm{~g} / \mathrm{kg})$ and $\mathrm{P}(6 \cdot 1 \mathrm{~g} / \mathrm{kg})$. The soyabean meal was analysed for crude protein $(430.4 \mathrm{~g} / \mathrm{kg})$, crude fat $(19.2 \mathrm{~g} / \mathrm{kg})$, crude fibre $(58.8 \mathrm{~g} / \mathrm{kg})$ and $\mathrm{P}(6.3 \mathrm{~g} / \mathrm{kg})$. L-Carnitine (Carniking ${ }^{\mathrm{TM}}, 50 \%$ purity) was obtained from Lonza Inc. The contents of crude protein, crude fat, crude fibre and $\mathrm{P}$ were assayed in our laboratory according to the procedures described by the AOAC (Association of Official Analytical Chemists) ${ }^{(16)}$

\section{Animals and experimental design}

This study was performed in strict accordance with recommendations of the National Research Council Guide ${ }^{(62)}$, and all of the animal experimental procedures were approved by the Ethical and Animal Welfare Committee of Heilongjiang Province, China (2008).

A total of 120 cross-bred (Landrace $\times$ Large White crossed with Duroc boar) multiparity gestation sows with an average parity of $4 \cdot 2$ (SEM 0.2) and their offspring were used in the study. At service, sows (230 (SEM 4.2) kg) were blocked by body weight (BW) and service date and randomly assigned to four groups of thirty each. The experiment was designed as $2 \times 2$ factorial with two dietary treatments (soyabean meal $v$. DDGS) and two L-carnitine levels

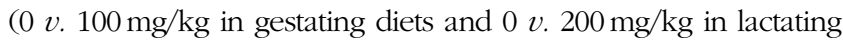
diets). The experimental treatments were as follows - from 1 to $90 \mathrm{~d}$ of gestation: (1) $160 \mathrm{~g} / \mathrm{kg}$ soyabean meal; (2) $250 \mathrm{~g} / \mathrm{kg}$ DDGS; (3) $160 \mathrm{~g} / \mathrm{kg}$ soyabean meal $+100 \mathrm{mg} / \mathrm{kg}$ L-carnitine; and (4) $250 \mathrm{~g} / \mathrm{kg}$ DDGS $+100 \mathrm{mg} / \mathrm{kg}$ L-carnitine; from $90 \mathrm{~d}$ of gestation to $21 \mathrm{~d}$ of lactation: (1) $278 \mathrm{~g} / \mathrm{kg}$ soyabean meal; (2) $400 \mathrm{~g} / \mathrm{kg}$ DDGS; (3) $278 \mathrm{~g} / \mathrm{kg}$ soyabean meal $+200 \mathrm{mg} / \mathrm{kg}$ L-carnitine; and (4) $400 \mathrm{~g} / \mathrm{kg}$ DDGS $+200 \mathrm{mg} / \mathrm{kg}$ L-carnitine. The composition and analysis of the dietary treatments (Tables 1 and 2) were compared using validated analytical methods (National Standards of the People's Republic of China, GB/T 19540-2004).

The sows were kept in single crates until day 30 of pregnancy. From day 30 to day 110 of pregnancy, the sows were kept in groups of six in pens that had fully slatted floors. On day 110 of pregnancy, the sows were moved to the farrowing accommodation where they were housed in single farrowing pens. The farrowing room temperature was maintained at approximately $18-20^{\circ} \mathrm{C}$. Within $2 \mathrm{~d}$ after farrowing, all piglets were earmarked according to the ear marks of their mothers. Piglets removed from sows and piglets given to sows were selected on the basis of their BW. At day 3, piglets received an Fe injection. At day 7, male piglets were castrated. The piglets were weaned on day 21 . Then, 400 piglets (100 piglets/treatment) with similar weight were moved to post-weaning rooms set at $27^{\circ} \mathrm{C}$ for the first $3 \mathrm{~d}$ and then gradually reduced to $22^{\circ} \mathrm{C}$. Piglets were housed in pens with woven-wire flooring with ten piglets per pen. After $55 \mathrm{~d}$, a total of 120 offspring with similar weight (regardless of sex) were moved to finishing barns with total concrete slat flooring. In all, thirty piglets were selected from each sow treatment. There were six pens per treatment and five pigs per pen. All offspring were fed the same diets (Table 2) and provided free access to water and the standard diet throughout the experiment. All of the experimental diets were formulated to meet or exceed the recommended requirements of the National Research Council ${ }^{(62)}$. The basal concentration of $\mathrm{L}$-carnitine was $<5 \mathrm{mg} / \mathrm{kg}$ in all feed mixtures used.

\section{Sample collection}

Piglets were selected from each treatment as follows: twenty-four similar average-weight piglets (at birth mean 1.4 (SEM 0.01) kg and weaning mean 5.6 (SEM 0.06) kg) regardless of sex were selected (six piglets per treatment) and slaughtered by an intra-arterial injection of pentobarbital $(200 \mathrm{mg} / \mathrm{kg})$ after general anaesthesia. The twenty-four slaughtered newborn piglets were selected from twenty-four sows (six sows per treatment, one piglet per sow) without fostered piglets. The selected newborn piglets were removed from their mothers immediately after birth and without sucking colostrum to exclude the effects of nutrients in the colostrum on their intestinal barrier functions. The slaughtered weaning piglets were selected from their mothers (six sows per treatment, one piglet per sow), which corresponded to the mothers of slaughtered newborn piglets, respectively. In all, twenty-four growing-finishing pigs with a similar weight of 110 (SEM 4.6) $\mathrm{kg}$ and regardless of sex from the four treatments (six pens per treatment, a pig per pen) were transported to the abattoir for slaughter. The twenty-four slaughtered growing-finishing pigs were born of sows (one piglet per sow), which corresponded to the mothers of slaughtered newborn and weaning piglets according to their ear marks. The abdomen was immediately opened to remove the entire small and large intestines. The small intestine and the caecum were carefully dissected from the mesentery, emptied and sampled. On the basis of previous reports on piglets and rats ${ }^{(35,36)}$, we designated the middle part of the jejunum. One part of mucosal scrapings from the jejunum was prepared frozen in liquid $\mathrm{N}_{2}$ and stored at $-80^{\circ} \mathrm{C}$ for further analyses of cytokines and tight junction protein mRNA expressions. The other part of the mucosal scrapings from the jejunum was sealed into pockets and preserved at $-20^{\circ} \mathrm{C}$ until used for the evaluation of antioxidant status. The contents (approximately $3 \mathrm{~g}$ ) of the caecum, which was divided into three equally long segments, were collected from the middle section and 
Table 1. Composition of experiment diets for sows (as fed basis)

\begin{tabular}{|c|c|c|c|c|c|c|c|c|}
\hline \multirow[b]{3}{*}{ Items (g/kg) } & \multicolumn{4}{|c|}{ Gestating diets } & \multicolumn{4}{|c|}{ Lactating diets } \\
\hline & \multicolumn{2}{|c|}{ No L-carnitine } & \multicolumn{2}{|c|}{ L-Carnitine } & \multicolumn{2}{|c|}{ No L-carnitine } & \multicolumn{2}{|c|}{ L-Carnitine } \\
\hline & Soyabean meal & DDGS & Soyabean meal & DDGS & Soyabean meal & DDGS & Soyabean meal & DDGS \\
\hline \multicolumn{9}{|l|}{ Ingredients } \\
\hline Maize & $624 \cdot 0$ & 541.5 & 623.9 & 541.4 & $634 \cdot 6$ & $497 \cdot 5$ & 634.4 & $497 \cdot 3$ \\
\hline Soyabean meal (430.4 CP g/kg) & $160 \cdot 0$ & - & $160 \cdot 0$ & - & 278.0 & - & 278.0 & - \\
\hline Wheat bran & $180 \cdot 0$ & $170 \cdot 0$ & $180 \cdot 0$ & $170 \cdot 0$ & - & - & - & - \\
\hline DDGS $(295.7 \mathrm{CP} g / \mathrm{kg})$ & - & $250 \cdot 0$ & - & $250 \cdot 0$ & - & $400 \cdot 0$ & - & $400 \cdot 0$ \\
\hline Maize gluten meal $(635.0 \mathrm{CP}$ g/kg) & - & - & - & - & $25 \cdot 0$ & $35 \cdot 0$ & $25 \cdot 0$ & $35 \cdot 0$ \\
\hline Soyabean oil & - & - & - & - & $20 \cdot 0$ & $20 \cdot 0$ & $20 \cdot 0$ & $20 \cdot 0$ \\
\hline L-Lysine-HCl $(980.0 \mathrm{~g} / \mathrm{kg})$ & - & 3.5 & - & 3.5 & 0.5 & $7 \cdot 0$ & 0.5 & $7 \cdot 0$ \\
\hline L-Tryptophan & - & - & - & - & - & 0.5 & - & 0.5 \\
\hline Limestone & $10 \cdot 0$ & $11 \cdot 0$ & $10 \cdot 0$ & $11 \cdot 0$ & $9 \cdot 3$ & $12 \cdot 0$ & $9 \cdot 3$ & $12 \cdot 0$ \\
\hline Calcium phosphate & $11 \cdot 0$ & $9 \cdot 0$ & $11 \cdot 0$ & $9 \cdot 0$ & $17 \cdot 6$ & $13 \cdot 0$ & $17 \cdot 6$ & $13 \cdot 0$ \\
\hline Salt & $5 \cdot 0$ & $5 \cdot 0$ & $5 \cdot 0$ & $5 \cdot 0$ & $5 \cdot 0$ & $5 \cdot 0$ & $5 \cdot 0$ & $5 \cdot 0$ \\
\hline Vitamin and mineral premix ${ }^{*}$ & $10 \cdot 0$ & $10 \cdot 0$ & $10 \cdot 0$ & $10 \cdot 0$ & $10 \cdot 0$ & $10 \cdot 0$ & $10 \cdot 0$ & $10 \cdot 0$ \\
\hline L-Carnitine & - & - & 0.1 & 0.1 & - & - & 0.2 & 0.2 \\
\hline \multicolumn{9}{|l|}{ Analysed composition $(\mathrm{g} / \mathrm{kg}) \dagger$} \\
\hline Metabolisable energy (MJ/kg) $\ddagger$ & $12 \cdot 2$ & $12 \cdot 2$ & $12 \cdot 2$ & $12 \cdot 2$ & 13.0 & 13.0 & 13.0 & $13 \cdot 0$ \\
\hline $\mathrm{CP}$ & $145 \cdot 7$ & 145.4 & $145 \cdot 7$ & 145.4 & 185.4 & 184.5 & 185.4 & 184.5 \\
\hline Crude fat & 31.9 & $50 \cdot 7$ & 31.9 & $50 \cdot 7$ & 48.5 & $79 \cdot 1$ & 48.5 & $79 \cdot 1$ \\
\hline Crude fibre & $31 \cdot 2$ & 37.5 & $31 \cdot 2$ & 37.5 & 28.5 & $36 \cdot 8$ & 28.5 & $36 \cdot 8$ \\
\hline $\mathrm{Ca}$ & 6.9 & 7.0 & 6.9 & 7.0 & $8 \cdot 2$ & $8 \cdot 2$ & $8 \cdot 2$ & $8 \cdot 2$ \\
\hline Total P & $6 \cdot 2$ & $6 \cdot 1$ & $6 \cdot 2$ & $6 \cdot 1$ & $6 \cdot 4$ & $6 \cdot 1$ & $6 \cdot 4$ & $6 \cdot 1$ \\
\hline Lys & $6 \cdot 6$ & 6.5 & $6 \cdot 6$ & 6.5 & $9 \cdot 4$ & $9 \cdot 4$ & $9 \cdot 4$ & $9 \cdot 4$ \\
\hline Trp & 1.6 & $1 \cdot 2$ & 1.6 & $1 \cdot 2$ & $2 \cdot 0$ & $1 \cdot 7$ & $2 \cdot 0$ & 1.7 \\
\hline Thr & $5 \cdot 2$ & $4 \cdot 7$ & $5 \cdot 2$ & $4 \cdot 7$ & $6 \cdot 8$ & $6 \cdot 1$ & $6 \cdot 8$ & $6 \cdot 1$ \\
\hline Met + Cys & 4.5 & $4 \cdot 8$ & 4.5 & 4.8 & 5.9 & $6 \cdot 4$ & $5 \cdot 9$ & $6 \cdot 4$ \\
\hline
\end{tabular}

DDGS, maize distillers dried grains with soluble; $\mathrm{CP}$, crude protein.

* Provided the following per $\mathrm{kg}$ of diet: $3.6 \mathrm{mg}$ of vitamin A, $62.5 \mu \mathrm{g}$ of vitamin $\mathrm{D}_{3}, 65.8 \mathrm{mg}$ of vitamin $\mathrm{E}, 3.6 \mathrm{mg}$ of vitamin $\mathrm{K}, 1.7 \mathrm{mg}$ of thiamin, $7.0 \mathrm{mg}$ of riboflavin, $1.6 \mathrm{mg}$ of pyridoxine, $0.3 \mathrm{mg}$ of vitamin $\mathrm{B}_{12}, 35 \mathrm{mg}$ of niacin, $15 \mathrm{mg}$ of pantothenic acid, $3.5 \mathrm{mg}$ of folic acid, $0.4 \mathrm{mg}$ of biotin, $0.33 \mathrm{mg}$ of antioxidant, $120 \mathrm{mg}$ of $\mathrm{Fe}$ as FeSO $\mathrm{F}_{4} \cdot \mathrm{H}_{2} \mathrm{O}, 21.25 \mathrm{mg}$ of $\mathrm{Cu}$ as $\mathrm{CuSO}_{4} \cdot 5 \mathrm{H}_{2} \mathrm{O}, 39 \cdot 75 \mathrm{mg}$ of $\mathrm{Mn}$ as $\mathrm{MnSO}_{4} \cdot \mathrm{H}_{2} \mathrm{O}, 101 \cdot 25 \mathrm{mg}$ of $\mathrm{Zn}$ as $\mathrm{ZnSO}_{4} \cdot \mathrm{H}_{2} \mathrm{O}, 0.3 \mathrm{mg}$ of Se as $\mathrm{Na}_{2} \mathrm{SeO}_{3}, 0.4 \mathrm{mg}$ of I as KI .

$\dagger$ Analysed values.

$\ddagger$ Calculated values according to the tables of feed composition and nutritive values in China (Xiong et al. ${ }^{(63)}$ ).

immediately frozen in liquid $\mathrm{N}_{2}$ and stored at $-80^{\circ} \mathrm{C}$ until analysis for microbial DNA.

\section{Analytical methods}

Approximately $1 \mathrm{~g}$ of mucosal scrapings was homogenised after being suspended in $9 \mathrm{ml}$ of PBS. After centrifugation at $3000 \mathrm{rpm}$ for $15 \mathrm{~min}$, the supernatant was taken for the measurement of the total superoxide dismutase (SOD), reduced glutathione (GSH), malondialdehyde (MDA) and cytokine concentrations. All antioxidant parameters were measured with the method of assay kits supplied by Nanjing Jiancheng Bioengineering Institute $^{(17,18)}$. Mucosal levels of IL- $1 \beta$, IL- 6 , IL-12 and TNF- $\alpha$ were measured using ELISA kits in accordance with the manufacturers' instructions (Experimental Equipment Co. Ltd).

Total DNA extraction from the middle section of the caecum samples was extracted using the TIANamp Stool DNA Kit (Tiangen Biotech, Ltd) according to the instructions of the manufacturer. The quantity and quality of DNA was assessed using a NanoPhotometer-P330 spectrophotometer (Implen $\mathrm{GmbH}$ ). Primers for total eubacteria, Lactobacillus spp., Enterobacteriaceae, bifidobacteria spp. and Clostridium cluster XIVa were designed according to previously published data $^{(19-24)}$. The primers (Table 3) were used for the estimation of select bacterial groups by quantitative real-time PCR using the ABI 7500 Real-Time PCR system (Applied Biosystems Limited). For bacterial groups, real-time PCR used the SYBR ${ }^{\circledR}$ Premix Ex Taq $^{\text {TM }}$ II system (TaKaRa ${ }^{\circledR}$ Bio Catalog). The PCR was run in a volume of $20 \mu \mathrm{l}$, with $10 \mu \mathrm{l}$ of $\mathrm{SYBR}^{\circledR}$ Premix Ex Taq $^{\mathrm{TM}}, 0 \cdot 8 \mu \mathrm{l}$ of each primer $(0.4 \mu \mathrm{M}), 0.4 \mu \mathrm{l}$ of ROX Reference Dye II (TaKaRa), $6 \cdot 0 \mu \mathrm{l}$ of double-distilled water and $2 \mu \mathrm{l}$ of DNA template. The thermal cycling conditions involved an initial denaturation step at $95^{\circ} \mathrm{C}$ for $5 \mathrm{~min}$, followed by forty cycles of $95^{\circ} \mathrm{C}$ for $15 \mathrm{~s}$ and $72^{\circ} \mathrm{C}$ for $30 \mathrm{~s}$. Dissociation analyses of the PCR products were carried out to confirm the specificity of the resulting PCR products. Quantification was performed in duplicate, and the mean values were calculated. The results were reported as $\log _{10} 16 \mathrm{~S}$ ribosomal DNA gene copies per gram fresh matter.

Total RNA was extracted from approximately $100 \mathrm{mg}$ of frozen jejunal tissues using the reagent box of the Total RNA Kit (E.Z.N.A. ${ }^{\circledR}$, Omega Bio-tek, Inc.), according to the manufacturer's instructions. The concentration of RNA was measured by using a spectrophotometer, and the purity was ascertained by the A260:A280 ratio. The total RNA from each sample was RT complementary DNA (cDNA) using the Prime Script ${ }^{\circledR}$ RT reagent Kit (TaKaRa ${ }^{\circledR}$ Bio Catalog), according to the manufacturer's instructions, and the cDNA was used for RT-PCR. The SYBR Green I RT-PCR Kit (TaKaRa ${ }^{\circledR}$ Bio Catalog) was used to measure the mRNA expression of tight junctions (claudin 1, zonula occludens-1 (ZO-1) and occludin) relative to the 
Table 2. Composition of diets for offspring (as fed basis)

\begin{tabular}{|c|c|c|c|c|c|}
\hline \multirow[b]{2}{*}{ Items (g/kg) } & \multicolumn{2}{|c|}{ Nurse period } & \multicolumn{2}{|c|}{ Growing period } & \multirow[b]{2}{*}{ Fattening period $(60-110 \mathrm{~kg})$} \\
\hline & $5-10 \mathrm{~kg}$ & $10-25 \mathrm{~kg}$ & $25-45 \mathrm{~kg}$ & $45-60 \mathrm{~kg}$ & \\
\hline \multicolumn{6}{|l|}{ Ingredients } \\
\hline Maize & 535.3 & $600 \cdot 1$ & 592.6 & 655.5 & 694.5 \\
\hline Soyabean meal (430.4 CP g/kg) & $250 \cdot 0$ & $260 \cdot 0$ & $230 \cdot 0$ & $250 \cdot 0$ & $200 \cdot 0$ \\
\hline Fishmeal $(660 \mathrm{CP} / \mathrm{kg})$ & $50 \cdot 0$ & $50 \cdot 0$ & $50 \cdot 0$ & - & - \\
\hline Soyabean oil & $50 \cdot 0$ & $50 \cdot 0$ & $50 \cdot 0$ & $20 \cdot 0$ & $20 \cdot 0$ \\
\hline Full-fat soyabean & $70 \cdot 0$ & - & - & - & - \\
\hline Wheat bran & - & - & $50 \cdot 0$ & $50 \cdot 0$ & $60 \cdot 0$ \\
\hline Limestone & 8.0 & $9 \cdot 0$ & 8.5 & 8.0 & 7.5 \\
\hline Calcium phosphate & $17 \cdot 0$ & 14.5 & $9 \cdot 0$ & 8.0 & 9.5 \\
\hline Salt & 3.5 & 3.5 & 3.5 & 3.5 & 3.5 \\
\hline Vitamin and mineral premix ${ }^{\star}$ & $5 \cdot 0$ & $5 \cdot 0$ & - & - & - \\
\hline Vitamin and mineral premix $\dagger$ & - & - & $5 \cdot 0$ & - & - \\
\hline Vitamin and mineral premix $\ddagger$ & - & - & - & 5.0 & $5 \cdot 0$ \\
\hline L-Lysine-HCl $(980.0 \mathrm{~g} / \mathrm{kg})$ & 3.0 & 1.5 & 0.7 & - & - \\
\hline DL-Methionine $(990.0 \mathrm{~g} / \mathrm{kg})$ & 1.4 & 0.6 & 0.4 & - & - \\
\hline L-Threonine $(990.0 \mathrm{~g} / \mathrm{kg})$ & 1.0 & - & - & - & - \\
\hline Tiamulin $(22 \mathrm{~g} / \mathrm{kg})$ & 1.8 & 1.8 & - & - & - \\
\hline Chlortetracycline $(110 \mathrm{~g} / \mathrm{kg})$ & $4 \cdot 0$ & 4.0 & 0.3 & - & - \\
\hline \multicolumn{6}{|l|}{ Analysed composition $(\mathrm{g} / \mathrm{kg}) \S$} \\
\hline $\mathrm{CP}$ & $213 \cdot 2$ & 194.6 & $185 \cdot 1$ & $164 \cdot 4$ & $147 \cdot 6$ \\
\hline Metabolisable energy (MJ/kg) & 13.7 & 13.6 & 13.6 & $13 \cdot 1$ & $13 \cdot 0$ \\
\hline Crude fat & $90 \cdot 4$ & $79 \cdot 7$ & 81.4 & $49 \cdot 6$ & $50 \cdot 1$ \\
\hline Crude fibre & 28.5 & $26 \cdot 9$ & $27 \cdot 9$ & $30 \cdot 0$ & $28 \cdot 0$ \\
\hline $\mathrm{Ca}$ & 9.7 & 9.4 & 8.0 & $5 \cdot 7$ & $5 \cdot 7$ \\
\hline Total P & 7.5 & $7 \cdot 1$ & $6 \cdot 4$ & $5 \cdot 1$ & $5 \cdot 2$ \\
\hline Lys & 14.5 & $12 \cdot 1$ & $10 \cdot 8$ & 8.2 & $7 \cdot 1$ \\
\hline $\operatorname{Trp}$ & 2.5 & $2 \cdot 2$ & $2 \cdot 1$ & 1.9 & 1.6 \\
\hline Thr & $9 \cdot 3$ & 7.6 & $7 \cdot 1$ & $6 \cdot 2$ & 5.5 \\
\hline Met & 4.9 & 3.9 & 3.5 & 2.5 & $2 \cdot 2$ \\
\hline
\end{tabular}

$\mathrm{CP}$, crude protein.

* Provided the following per $\mathrm{kg}$ of diet: $3.3 \mathrm{mg}$ of vitamin $\mathrm{A}, 68.9 \mu \mathrm{g}$ of vitamin $\mathrm{D}_{3}, 66 \mathrm{mg}$ of vitamin $\mathrm{E}, 4.4 \mathrm{mg}$ of vitamin $\mathrm{K}, 1.1 \mathrm{mg}$ of thiamin, $9.9 \mathrm{mg}$ of riboflavin, $2.2 \mathrm{mg}$ of pyridoxine, $0.1 \mathrm{mg}$ of vitamin $\mathrm{B}_{12}, 55 \mathrm{mg}$ of niacin, $55 \mathrm{mg}$ of pantothenic acid, $1.7 \mathrm{mg}$ of folic acid, $0.4 \mathrm{mg}$ of biotin, $0.33 \mathrm{mg}$ of antioxidant, $105 \mathrm{mg}$ of $\mathrm{Fe}$ as $\mathrm{FeSO}_{4} \cdot \mathrm{H}_{2} \mathrm{O}, 6 \mathrm{mg}$ of $\mathrm{Cu}$ as $\mathrm{CuSO}_{4} \cdot 5 \mathrm{H}_{2} \mathrm{O}, 28 \cdot 62 \mathrm{mg}$ of $\mathrm{Mn}$ as $\mathrm{MnSO}_{4} \cdot \mathrm{H}_{2} \mathrm{O}, 110 \cdot 06 \mathrm{mg}$ of $\mathrm{Zn}$ as ZnSO $4 \cdot \mathrm{H}_{2} \mathrm{O}, 0.3 \mathrm{mg}$ of Se as $\mathrm{Na}_{2} \mathrm{SeO}_{3}, 0.14 \mathrm{mg}$ of I as $\mathrm{KI}$.

† Provided the following per $\mathrm{kg}$ of diet: $2.6 \mathrm{mg}$ of vitamin $\mathrm{A}, 41.3 \mu \mathrm{g}$ of vitamin $\mathrm{D}_{3}, 33 \mathrm{mg}$ of vitamin $\mathrm{E}, 3.3 \mathrm{mg}$ of vitamin $\mathrm{K}, 1.1 \mathrm{mg}$ of thiamin, $5.5 \mathrm{mg}$ of riboflavin, $2.0 \mathrm{mg}$ of pyridoxine, $0.03 \mathrm{mg}$ of vitamin $\mathrm{B}_{12}, 33 \mathrm{mg}$ of niacin, $22 \mathrm{mg}$ of pantothenic acid, $1.0 \mathrm{mg}$ of folic acid, $0.1 \mathrm{mg}$ of biotin, $0.33 \mathrm{mg}$ of antioxidant, $114 \mathrm{mg}$ of $\mathrm{Fe}$ as $\mathrm{FeSO}_{4} \cdot \mathrm{H}_{2} \mathrm{O}, 6 \mathrm{mg}$ of $\mathrm{Cu}$ as $\mathrm{CuSO}_{4} \cdot 5 \mathrm{H}_{2} \mathrm{O}, 14.31 \mathrm{mg}$ of $\mathrm{Mn}$ as $\mathrm{MnSO}_{4} \cdot \mathrm{H}_{2} \mathrm{O}, 70 \mathrm{mg}$ of $\mathrm{Zn}$ as $\mathrm{ZnSO} \cdot \mathrm{H}_{2} \mathrm{O}, 0.3 \mathrm{mg}$ of Se as $\mathrm{Na}_{2} \mathrm{SeO}_{3}, 0.14 \mathrm{mg}$ of I as $\mathrm{KI}$.

₹ Provided the following per $\mathrm{kg}$ of diet: $2.6 \mathrm{mg}$ of vitamin $\mathrm{A}, 41.3 \mu \mathrm{g}$ of vitamin $\mathrm{D}_{3}, 33 \mathrm{mg}$ of vitamin $\mathrm{E}, 3.3 \mathrm{mg}$ of vitamin $\mathrm{K}, 1.1 \mathrm{mg}$ of thiamin, $5.5 \mathrm{mg}$ of riboflavin, $2.0 \mathrm{mg}$ of pyridoxine, $0.03 \mathrm{mg}$ of vitamin $\mathrm{B}_{12}, 33 \mathrm{mg}$ of niacin, $22 \mathrm{mg}$ of pantothenic acid, $1.0 \mathrm{mg}$ of folic acid, $0.1 \mathrm{mg}$ of biotin, $0.33 \mathrm{mg}$ of antioxidant, $90 \mathrm{mg}$ of $\mathrm{Fe}$ as $\mathrm{FeSO}_{4} \cdot \mathrm{H}_{2} \mathrm{O}, 5 \mathrm{mg}$ of $\mathrm{Cu}$ as $\mathrm{CuSO}_{4} \cdot 5 \mathrm{H}_{2} \mathrm{O}, 14 \cdot 31 \mathrm{mg}$ of $\mathrm{Mn}$ as $\mathrm{MnSO}_{4} \cdot \mathrm{H}_{2} \mathrm{O}, 69 \mathrm{mg}$ of $\mathrm{Zn}$ as $\mathrm{ZnSO}{ }_{4} \cdot \mathrm{H}_{2} \mathrm{O}, 0 \cdot 3 \mathrm{mg}$ of Se as $\mathrm{Na}_{2} \mathrm{SeO}_{3}, 0.14 \mathrm{mg}$ of I as $\mathrm{KI}$.

$\S$ Analysed values.

Table 3. Primers used for real-time PCR to detect bacterial numbers

\begin{tabular}{|c|c|c|c|c|}
\hline $\begin{array}{l}\text { Targeted bacterial group } \\
\text { (amplicon size) }\end{array}$ & Item & Primer sequence $\left(5^{\prime}-3^{\prime}\right)$ & $\begin{array}{c}\text { Annealing } \\
\text { temperature }\left({ }^{\circ} \mathrm{C}\right)\end{array}$ & References \\
\hline Total eubacteria (200 bp) & $\begin{array}{l}\text { Forward } \\
\text { Reverse }\end{array}$ & $\begin{array}{l}\text { CGGYCCAGACTCCTACGGG } \\
\text { TTACCGCGGCTGCTGGCAC }\end{array}$ & 58 & Lee et al. ${ }^{(19)}$ \\
\hline Lactobacillus spp. (341 bp) & $\begin{array}{l}\text { Forward } \\
\text { Reverse }\end{array}$ & $\begin{array}{l}\text { AGCAGTAGGGAATCTTCCA } \\
\text { CACCGCTACACATGGAG }\end{array}$ & 62 & Walter et al. ${ }^{(20)}$ and Heilig et al. ${ }^{(21)}$ \\
\hline Enterobacteriaceae (195 bp) & $\begin{array}{l}\text { Forward } \\
\text { Reverse }\end{array}$ & $\begin{array}{l}\text { CATTGACGTTACCCGCAGAAGAAGC } \\
\text { CTCTACGAGACTCAAGCTTGC }\end{array}$ & 60 & Bartosch et al. ${ }^{(22)}$ \\
\hline Bifidobacteria spp. (243bp) & $\begin{array}{l}\text { Forward } \\
\text { Reverse }\end{array}$ & $\begin{array}{l}\text { TCGCGTC(C/T)GGTGTGAAAG } \\
\text { CCACATCCAGC(A/G)TCCAC }\end{array}$ & 58 & Rinttila et al. ${ }^{(23)}$ \\
\hline Clostridium cluster XIVa (440 bp) & $\begin{array}{l}\text { Forward } \\
\text { Reverse }\end{array}$ & $\begin{array}{l}\text { AAATGACGGTACCTGACTAA } \\
\text { CTTTGAGTTTCATTCTTGCGAA }\end{array}$ & 58 & Matsuki et al. ${ }^{(24)}$ \\
\hline
\end{tabular}

expression of the $\beta$-actin endogenous control. Specific primers were designed using the Primer Express ${ }^{\circledR}$ software (PE Applied Biosystems) and were synthesised by Sangon Biological
Engineering Co. Ltd. Primer sequence data are presented in Table 4. For analyses on an ABI PRISM 7500 SDS thermal cycler (Applied Biosystems), the reactions were performed 
Table 4. Sequence of primers for tight junction genes

\begin{tabular}{lllcl}
\hline Genes & Item & Primer sequence $\left(5^{\prime}-3^{\prime}\right)$ & Product length & GenBank number \\
\hline Occludin & Forward & GAGTACATGGCTGCTGCTGA & 173 & NM_001163647.2 \\
& Reverse & AACAAGGTGGCCTCTGTCTC & 217 & XM_005659811.1 \\
ZO-1 & Forward & AGCTGCCTCTCAACAGAAAG & & \\
& Reverse & GTCTCTGGGCACTGTGTGAG & 137 & NM_001244539.1 \\
Claudin 1 & Forward & CTGAACACCACTTTGCAAGC & AY550069 \\
$\beta$-Actin & Reverse & ATCCGCATCTTCTGCACCTC & 211 & \\
& Forward & ATGCTTCTAGGCGGACTGT & & \\
\hline
\end{tabular}

ZO-1, zonula occludens-1

with $2.0 \mu \mathrm{l}$ of first-strand cDNA and $0.4 \mu \mathrm{m}$ of sense and antisense primers in a final volume of $20 \mu \mathrm{l}$. The samples were centrifuged briefly and run on the PCR machine using the default fast programme (one cycle at $95^{\circ} \mathrm{C}$ for $30 \mathrm{~s}$, forty cycles of $95^{\circ} \mathrm{C}$ for $5 \mathrm{~s}$ and $60^{\circ} \mathrm{C}$ for $34 \mathrm{~s}$ ). The relative gene expression levels were determined using the $2^{-\Delta \Delta C_{t}} \operatorname{method}^{(25)}$.

\section{Statistical analysis}

Bacterial gene copies were transformed $\left(\log _{10}\right)$ before statistical analysis. Data were analysed by ANOVA using the general linear model procedure of SPSS 17.0 (IBM-SPSS Inc.). The results were presented by mean values with their standard errors. The statistical model included the main effects of maternal diet, L-carnitine and piglet age, the interactions of maternal diet $\times$ L-carnitine, maternal diet $\times$ piglet age, L-carnitine $\times$ piglet age and maternal diet $\times_{\mathrm{L}-\text { carnitine }} \times$ piglet age. Differences were considered significant at $P<0 \cdot 05$.

\section{Results}

There were no significant interaction effects between dietary treatment and L-carnitine in gestating and lactating sows on the antioxidant capacity, concentrations of cytokines and the tight junction protein expression of jejunal mucosa in their offspring.

\section{Antioxidant capacity}

Table 5 shows that dietary supplementation with L-carnitine in gestating and lactating sows increased the SOD activity of the jejunal mucosa in newborn piglets and weaning piglets on day $21(P<0 \cdot 05)$. Dietary supplementation with $\mathrm{L}$-carnitine in gestating and lactating sows decreased the concentration of MDA of the jejunal mucosa in newborn and weaning piglets on day $21(P<0 \cdot 01)$. There were no differences in the antioxidant capacity of jejunal mucosa in growing-finishing pigs. Age significantly influenced the antioxidant capacity of jejunal muscosa in their offspring $(P<0.001)$, but there were no interaction effects between age and treatments $(P>0 \cdot 05)$ (Table 5).

\section{Concentrations of cytokines}

Table 7 shows that dietary supplementation with L-carnitine in gestating and lactating sows decreased the concentrations of IL- $1 \beta$, IL-12 and TNF- $\alpha$ in the jejunal mucosa of newborn piglets
$(P<0.05)$ and decreased the concentrations of IL-6 $(P<0.05)$ and TNF- $\alpha(P<0 \cdot 01)$ in the jejunal mucosa of weaning piglets on day 21. There were no differences in the concentrations of cytokine in the jejunal mucosa in growing-finishing pigs. Age significantly influenced the concentrations of cytokines in their offspring $(P<0 \cdot 001)$, and there were significant interaction effects between L-carnitine and age in the concentration of IL-6, IL-12 and TNF- $\alpha(P<0 \cdot 05)$. However, there were no interactions between dietary treatments and age, and also there were no interaction effects among the dietary treatments, L-carnitine and age $(P>0.05)$ (Table 6$)$.

\section{Bacterial numbers}

There was an interaction between dietary treatment and L-carnitine on the number of total eubacteria in the digesta of the caecum in weaning piglets on day $21(P=0 \cdot 046)$. The number of total eubacteria in weaning piglets was significantly increased by L-carnitine only in the soyabean meal diet $(P<0.05)$, but there was no significant effect of L-carnitine in the DDGS diet $(P>0 \cdot 05)$. Table 8 shows that dietary supplementation with L-carnitine increased the numbers of Lactobacillus spp. and bifidobacteria spp. in the digesta of the caecum in weaning piglets on day $21(P<0 \cdot 05)$. There were no differences in bacterial numbers in the digesta of the caecum in growing-finishing pigs. Age significantly influenced the number of Lactobacillus spp., Enterobacteriaceae and bifidobacteria spp. in their offspring $(P<0 \cdot 01)$, but there were no effects in the number of total eubacteria and Clostridium cluster XIVa $(P>0.05)$. There was no interaction between treatments and age $(P>0.05)$ (Table 7$)$.

\section{Gene expression of tight junction proteins}

The results of the expression of tight junction proteins showed that dietary supplementation with L-carnitine in gestating and lactating sows increased the expression of ZO-1 mRNA in the jejunal mucosa of newborn piglets $(P<0.01)$, and increased the expression of ZO-1 and occludin mRNA in the jejunal mucosa of weaning piglets on day $21(P<0 \cdot 05)$. There were no differences in the expression of tight junction proteins of the jejunal mucosa in growing-finishing pigs. Age influenced the expression of ZO-1 mRNA $(P<0.05)$ in their offspring, but there were no effects in the expression of claudin 1 and occludin mRNA $(P>0.05)$. In addition, there was no interaction between treatments and age $(P>0 \cdot 05)$ (Table 8$)$. 
Table 5. Effects of L-carnitine and/or maize distillers dried grains with solubles diets (DDGS) in diets of gestating and lactating sows on antioxidant capacity in the jejunal mucosa of their offspring

\begin{tabular}{|c|c|c|c|c|c|c|c|c|c|c|c|c|c|}
\hline \multirow[b]{2}{*}{ Items } & \multirow[b]{2}{*}{ Growing phase } & \multicolumn{2}{|c|}{ No L-carnitine } & \multicolumn{2}{|c|}{ L-Carnitine } & \multirow[b]{2}{*}{ SEM } & \multicolumn{2}{|c|}{$P$} & \multirow[b]{2}{*}{ SEM } & \multicolumn{4}{|c|}{$P$} \\
\hline & & SBM & DDGS & SBM & DDGS & & D & L & & A & $D \times A$ & $L \times A$ & $D \times L \times A$ \\
\hline \multirow{3}{*}{ MDA (nmol/g mucosa) } & Newborn & $48 \cdot 21$ & $57 \cdot 24$ & $30 \cdot 6$ & 33.04 & 3.649 & 0.327 & 0.003 & & & & & \\
\hline & Weaning & 72.58 & $62 \cdot 38$ & 49.97 & 41.01 & 3.893 & 0.134 & 0.002 & 1.836 & $<0.001$ & 0.211 & 0.620 & 0.421 \\
\hline & Growing-finishing & 66.91 & 73.53 & 51.04 & 61.60 & 3.782 & 0.788 & 0.074 & & & & & \\
\hline \multirow[t]{3}{*}{ SOD (U/mg mucosa) } & Newborn & 1.77 & 1.73 & $2 \cdot 14$ & 1.95 & 0.066 & 0.379 & 0.030 & & & & & \\
\hline & Weaning & 2.89 & 2.51 & 3.68 & 3.39 & 0.160 & 0.241 & 0.010 & 0.084 & $<0.001$ & 0.429 & 0.450 & 0.835 \\
\hline & Growing-finishing & 4.82 & 4.53 & 4.13 & 4.82 & 0.181 & 0.601 & 0.599 & & & & & \\
\hline \multirow[t]{3}{*}{ GSH (mg/g mucosa) } & Newborn & 0.26 & 0.25 & 0.30 & 0.27 & 0.014 & 0.430 & 0.341 & & & & & \\
\hline & Weaning & 0.30 & 0.27 & 0.33 & 0.29 & 0.015 & 0.286 & 0.345 & 0.008 & $<0.001$ & 0.799 & 0.839 & 0.990 \\
\hline & Growing-finishing & 0.18 & 0.18 & 0.19 & $0 \cdot 18$ & 0.009 & 0.704 & 0.662 & & & & & \\
\hline
\end{tabular}

SBM, soyabean meal diets; $D$, dietary treatments; L, L-carnitine; $A$, age; $D \times A$, dietary treatments $\times$ age interaction; $L \times A, L$-carnitine $\times$ age interaction; $D \times L \times A$, dietary treatments $\times L$-carnitine $\times$ age interaction; MDA, malondialdehyde; SOD, total superoxide dismutase; GSH, reduced glutathione.

Table 6. Effects of L-carnitine and/or maize distillers dried grains with solubles diets (DDGS) in diets of gestating and lactating sows on the concentrations of cytokines in the jejunal mucosa of their offspring

\begin{tabular}{|c|c|c|c|c|c|c|c|c|c|c|c|c|c|}
\hline \multirow[b]{2}{*}{ Items } & \multirow[b]{2}{*}{ Growing phase } & \multicolumn{2}{|c|}{ No L-carnitine } & \multicolumn{2}{|c|}{ L-Carnitine } & \multirow[b]{2}{*}{ SEM } & \multicolumn{2}{|c|}{$P$} & \multirow[b]{2}{*}{ SEM } & \multicolumn{4}{|c|}{$P$} \\
\hline & & SBM & DDGS & SBM & DDGS & & $\mathrm{D}$ & L & & A & $D \times A$ & $L \times A$ & $D \times L \times A$ \\
\hline \multirow[t]{3}{*}{ IL-1 $\beta$ (pg/g mucosa) } & Newborn & 242.50 & 239.08 & 231.65 & 231.65 & $15 \cdot 716$ & 0.628 & 0.021 & & & & & \\
\hline & Weaning & 251.03 & 261.90 & 253.56 & 251.54 & 15.986 & 0.266 & 0.323 & 1.031 & $<0.001$ & 0.341 & 0.126 & 0.281 \\
\hline & Growing-finishing & $196 \cdot 78$ & 202.99 & 199.01 & $203 \cdot 37$ & 11.542 & 0.129 & 0.700 & & & & & \\
\hline \multirow[t]{3}{*}{ IL-6 (ng/g mucosa) } & Newborn & 6.03 & 6.00 & $5 \cdot 82$ & 6.03 & 0.263 & 0.197 & 0.222 & & & & & \\
\hline & Weaning & 6.41 & 6.45 & $6 \cdot 23$ & $6 \cdot 33$ & 0.247 & 0.263 & 0.030 & 0.025 & $<0.001$ & 0.732 & 0.042 & 0.055 \\
\hline & Growing-finishing & 4.81 & 4.97 & 5.07 & 4.94 & 0.318 & 0.896 & 0.218 & & & & & \\
\hline \multirow[t]{3}{*}{ II-12 (ng/g mucosa) } & Newborn & 1.53 & 1.55 & 1.45 & 1.52 & 0.108 & 0.058 & 0.023 & & & & & \\
\hline & Weaning & 1.56 & 1.57 & 1.55 & 1.53 & 0.080 & 0.857 & 0.270 & 0.006 & $<0.001$ & 0.218 & 0.026 & 0.265 \\
\hline & Growing-finishing & 1.15 & $1 \cdot 18$ & 1.21 & 1.17 & 0.075 & 0.910 & 0.213 & & & & & \\
\hline \multirow[t]{3}{*}{ TNF- $a$ (ng/g mucosa) } & Newborn & 2.46 & 2.45 & 2.35 & 2.36 & 0.188 & 0.911 & 0.035 & & & & & \\
\hline & Weaning & 2.55 & $2 \cdot 61$ & 2.48 & 2.45 & 0.173 & 0.620 & 0.006 & 0.011 & $<0.001$ & 0.794 & 0.006 & 0.195 \\
\hline & Growing-finishing & 1.83 & 1.82 & 1.82 & 1.91 & 0.120 & 0.245 & 0.256 & & & & & \\
\hline
\end{tabular}

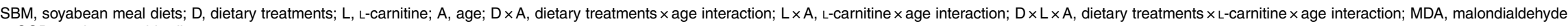
SOD, total superoxide dismutase. 
Table 7. Effects of L-carnitine and/or maize distillers dried grains with solubles diets (DDGS) in diets of gestating and lactating sows on bacterial numbers in the caecal digesta of their offspring*

\begin{tabular}{|c|c|c|c|c|c|c|c|c|c|c|c|c|c|}
\hline \multirow[b]{2}{*}{ Items } & \multirow[b]{2}{*}{ Growing phase } & \multicolumn{2}{|c|}{ No L-carnitine } & \multicolumn{2}{|c|}{ L-Carnitine } & \multirow[b]{2}{*}{ SEM } & \multicolumn{2}{|c|}{$P$} & \multirow[b]{2}{*}{ SEM } & \multicolumn{4}{|c|}{$P$} \\
\hline & & SBM & DDGS & SBM & DDGS & & D & L & & A & $D \times A$ & $L \times A$ & $D \times L \times A$ \\
\hline \multirow[t]{2}{*}{ Total eubacteria } & Weaning & $11 \cdot 15$ & 11.37 & 11.51 & 11.41 & 0.143 & 0.390 & 0.019 & 0.028 & 0.727 & 0.382 & 0.436 & 0.160 \\
\hline & Growing-finishing & 11.30 & 11.27 & 11.41 & 11.38 & 0.119 & 0.726 & 0.211 & & & & & \\
\hline \multirow[t]{2}{*}{ Lactobacillus spp. } & Weaning & 9.47 & 9.39 & 10.07 & $10 \cdot 26$ & 0.429 & 0.816 & 0.011 & 0.079 & 0.007 & 0.475 & 0.292 & 0.245 \\
\hline & Growing-finishing & 9.10 & $9 \cdot 16$ & 9.73 & 9.32 & 0.323 & 0.393 & 0.066 & & & & & \\
\hline \multirow[t]{2}{*}{ Enterobacteriaceae } & Weaning & 9.13 & 9.04 & 9.74 & 9.06 & 0.404 & 0.136 & 0.220 & 0.095 & 0.004 & 0.222 & 0.407 & 0.338 \\
\hline & Growing-finishing & 8.64 & 8.65 & 8.57 & 8.72 & 0.373 & 0.775 & 0.995 & & & & & \\
\hline \multirow[t]{2}{*}{ Bifidobacteria spp. } & Weaning & 6.62 & 7.04 & 8.58 & 7.72 & 0.370 & 0.711 & 0.040 & 0.149 & $<0.001$ & 0.837 & 0.083 & 0.209 \\
\hline & Growing-finishing & 5.53 & $5 \cdot 31$ & 5.65 & 5.69 & 0.346 & 0.707 & 0.326 & & & & & \\
\hline \multirow[t]{2}{*}{ Clostridium cluster XIVa } & Weaning & 9.60 & 9.54 & 9.66 & 9.52 & 0.179 & 0.066 & 0.703 & 0.053 & 0.446 & 0.688 & 0.580 & 0.749 \\
\hline & Growing-finishing & 9.54 & 9.64 & 9.79 & 9.67 & 0.276 & 0.947 & 0.490 & & & & & \\
\hline
\end{tabular}

SBM, soyabean meal diets; $D$, dietary treatments; $L$, L-carnitine; $A$, age; $D \times A$, dietary treatments $\times$ age interaction; $L \times A$, L-carnitine $\times$ age interaction; $D \times L \times A$, dietary treatments $\times L$-carnitine $\times$ age interaction.

* The results were reported as $\log _{10} 16 \mathrm{~S}$ ribosomal DNA gene copies/g fresh matter.

Table 8. Effects of L-carnitine and/or maize distillers dried grains with solubles diets (DDGS) in diets of gestating and lactating sows on tight junction mRNA expression in the jejunal mucosa of their offspring

\begin{tabular}{|c|c|c|c|c|c|c|c|c|c|c|c|c|c|}
\hline \multirow[b]{2}{*}{ Items } & \multirow[b]{2}{*}{ Growing phase } & \multicolumn{2}{|c|}{ No L-carnitine } & \multicolumn{2}{|c|}{ L-Carnitine } & \multirow[b]{2}{*}{ SEM } & \multicolumn{2}{|c|}{$P$} & \multirow[b]{2}{*}{ SEM } & \multicolumn{4}{|c|}{$P$} \\
\hline & & SBM & DDGS & SBM & DDGS & & D & L & & A & $D \times A$ & $L \times A$ & $D \times L \times A$ \\
\hline \multirow{3}{*}{ Claudin 1} & Newborn & 1.00 & 1.05 & 1.31 & 1.17 & 0.108 & 0.796 & 0.243 & & & & & \\
\hline & Weaning & 1.00 & 1.12 & 1.24 & 1.27 & 0.065 & 0.440 & 0.056 & 0.028 & 0.369 & 0.969 & 0.641 & 0.830 \\
\hline & Growing-finishing & 1.00 & $1 \cdot 10$ & $1 \cdot 18$ & $1 \cdot 17$ & 0.053 & 0.610 & 0.137 & & & & & \\
\hline \multirow[t]{3}{*}{ ZO-1 } & Newborn & 1.00 & 1.24 & 1.38 & 1.49 & 0.084 & 0.101 & 0.007 & & & & & \\
\hline & Weaning & 1.00 & 1.09 & 1.30 & 1.32 & 0.076 & 0.626 & 0.026 & 0.036 & 0.020 & 0.499 & 0.407 & 0.887 \\
\hline & Growing-finishing & 1.00 & 0.99 & $1 \cdot 11$ & 1.11 & 0.070 & 0.965 & 0.355 & & & & & \\
\hline \multirow[t]{3}{*}{ Occludin } & Newborn & 1.00 & 1.09 & 1.27 & $1 \cdot 17$ & 0.083 & 0.960 & 0.204 & & & & & \\
\hline & Weaning & 1.00 & 0.97 & $1 \cdot 13$ & 1.07 & 0.069 & 0.433 & 0.045 & 0.031 & 0.876 & 0.784 & 0.875 & 0.944 \\
\hline & Growing-finishing & 1.00 & 1.05 & $1 \cdot 12$ & 1.02 & 0.047 & 0.734 & 0.558 & & & & & \\
\hline
\end{tabular}

SBM, soyabean meal diets; D, dietary treatments; L, L-carnitine; A, age; $D \times A$, dietary treatments $\times$ age interaction; $L \times A$, L-carnitine $\times$ age interaction; $D \times L \times A$, dietary treatments $\times \mathrm{L}-$ carnitine $\times$ age interaction; ZO-1, zonula occludens-1. 


\section{Discussion}

The use of L-carnitine in the nutrition of pigs is increasingly discussed. There are several studies that found beneficial effects of L-carnitine supplementation on sows ${ }^{(10,26-28)}$. A few studies observed beneficial effects of L-carnitine supplementation on the growth performance or body composition of growing pigs ${ }^{(29-31)}$. However, the present study is the first one that investigates the effect of dietary treatment and L-carnitine in gestating and lactating sows on intestinal barrier functions of their offspring

As is known, there is a strong correlation among oxidative stress, inflammation, mucosal integrity and intestinal permeability. The activity of SOD is known to serve protective function for the elimination of reactive free radicals, and thus it represents an important antioxidant defence in nearly all cells exposed to oxygen ${ }^{(32)}$. GSH forms an important part of the nonenzymatic antioxidants. Similar to other sulfhydryl-containing products, GSH also has regulatory and protective roles in the body. It establishes the defence line of the body against tissue injury because of chemicals through its ROS scavenger, cell viability and membrane-stabilizing effects ${ }^{(33)}$. MDA is an end product of free-radical chain reaction and lipid peroxidation ${ }^{(34)}$, so it is frequently used in the measurement of lipid peroxide levels, and it provides a good correlation with the degree of lipid peroxidation ${ }^{(35)}$. In the present study, the results show that the activity of SOD was significantly increased in the newborn piglets and weaning piglets of sows supplemented with L-carnitine. The variational trend of MDA concentrations was opposite to that of SOD activity in piglets of gestating and lactating sows supplemented with L-carnitine. It has been clearly demonstrated that L-carnitine not only has an important role in the metabolism of lipids but is also a potent antioxidant $^{(13)}$. The findings may indicate that the abundance of antioxidants supplemented with mother's milk might reduce oxygen free radicals in piglets ${ }^{(36)}$. The results of the present study are consistent with previous conclusions that L-carnitine administration reduced the concentration of MDA, prevented the depletion of GSH levels and increased SOD activity ${ }^{(11,12,35)}$.

The gastrointestinal tract functions as a major immunological organ, as it must maintain tolerance to commensal and dietary antigens while remaining responsive to pathogenic stimuli. The intestinal immunity is closely related to other intestinal functions. Previous studies have suggested that a decrease in the inflammatory cytokine gene expression may promote a more stable ecosystem that may prevent the proliferation of some particular bacterial groups ${ }^{(37)}$. The over-production of proinflammatory cytokines has an adverse effect on intestinal mucosal integrity ${ }^{(38)}$. Recent studies have indicated that most pro-inflammatory cytokines, such as TNF- $\alpha$, interferon- $\gamma$, IL- $1 \beta$ and IL- 6 , induce a pathologic opening of the intestinal tight junction barrier and increase intestinal epithelial permeability $^{(39)}$. In the present study, dietary supplementation with L-carnitine in gestating and lactating sows decreased mucosal IL- $1 \beta$, IL-12 and TNF- $\alpha$ concentrations in newborn piglets and decreased mucosal IL- 6 and TNF- $\alpha$ concentrations in weaning piglets. L-Carnitine has been shown to affect humoral and cellular immune responses in mice ${ }^{(40)}$. It suppresses TNF- $\alpha$ and
IL-12 release from human monocytes in a glucocorticoid-like manner $^{(41)}$. L-Carnitine has also been shown to significantly decrease TNF- $\alpha$ and DNA damage ${ }^{(42)}$. Liu et $a l .{ }^{(43)}$ showed that the oral administration of L-carnitine reduced the serum concentrations of TNF- $\alpha$ or IL- 6 . The findings in the present study might be because an increase of the L-carnitine concentration in the fetus and milk $^{(8,44)}$ as a result of maternal supplementation with L-carnitine decreased mucosal cytokine concentrations in newborn and weaning piglets.

From simple to complex and being gradually stable with the increase of age, balanced intestinal flora is important for growth and health of piglets ${ }^{(45)}$. The most important beneficial effect of the indigenous microflora is creating a barrier to make it more difficult for exogenous pathogenic bacteria to colonise the gastrointestinal tract and cause disease, a phenomenon known as colonisation resistance ${ }^{(46)}$. The intestinal microbiota also has essential functions in host metabolism and in directing immune system development ${ }^{(47)}$. The pre-treatment of animals with bifidobacteria reduced pro-inflammatory cytokine release, the concentrations of endotoxin, intestinal epithelial cell apoptosis and disruption of tight junctions, resulting in recovered microbiota and mucosal integrity ${ }^{(48)}$. In vitro, the probiotic Lactobacillus has also been shown to up-regulate occludin and cingulin gene mRNA levels of Caco- 2 cells, suggesting that bacteria could affect the intestinal barrier integrity by regulating the gene expression of the tight junction proteins ${ }^{(49)}$. Indigenous Clostridium-dependent induction of Tregs may be required for maintaining immune homoeostasis in mice and humans ${ }^{(50)}$. The present study was aimed at detecting whether the L-carnitine in DDGS-based diet of gestating and lactating sows can affect the form of the intestinal flora in their offspring. As the results show, dietary supplementation with L-carnitine increased the number of Lactobacillus spp. and bifidobacteria spp. in the digesta of the caecum in weaning piglets. As we know, diet has a direct influence on the intestinal microbes of both composition and vitality of this community ${ }^{(51)}$. Interestingly, it has been found that breastfed European children have a microbiota depleted of Bacteroidetes and enriched in Enterobacteriaceae compared with rural breastfed African children, which the authors attributed to difference in maternal diet ${ }^{(52)}$. It has been suggested that maternal diet can influence the intestinal microbiota of the offspring. Furthermore, sows supplemented with L-carnitine have more milk production and piglets born to sows supplemented with L-carnitine are able to suckle for longer, which enables them to obtain more milk than piglets born to control sows ${ }^{(53)}$. Previous studies showed that sufficient feed intake during weaning encourages the proliferation of beneficial bacteria, thereby contributing to improved gut health ${ }^{(54)}$. Interestingly, the number of total eubacteria in weaning piglets was significantly increased by L-carnitine only in soyabean meal diet, but there was no significant effect of L-carnitine in the DDGS-based diet. Further research needs to be carried out to explore the effects of L-carnitine in the DDGS-based diet on intestinal microbiota.

Tight junction proteins (claudin 1, ZO-1 and occludin) have a crucial role in intestinal barrier integrity and permeability by sealing the paracellular space between epithelial cells, thus preventing the paracellular diffusion of intestinal bacteria and 
other antigens across the epithelium ${ }^{(55)}$. Wang et al. ${ }^{(48)}$ showed that the pre-treatment of animals with bifidobacteria reduced the disruption of tight junctions. Zhong et al. ${ }^{(56)}$ showed that the beneficial effect on the expression of occludin mRNA has been considered to be related to the greater number of lactobacilli and bifidobacteria, in agreement with the results in the present study. Pro-inflammatory cytokines have been shown to down-regulate gene expression of tight junction proteins ${ }^{(39,57)}$ through the dysregulation of tight junction proteins, resulting in the increase in intestinal permeability ${ }^{(58)}$. This is part of the reason why higher expression of ZO-1 and occludin mRNA were found in piglets born to sows supplemented with L-carnitine in the present study. Furthermore, the high concentration of L-carnitine in the offspring of sows supplemented with L-carnitine may exert an antioxidant property, decreasing lipid peroxidation and reactive oxygen species formation, possibly resulting in the increased expression of ZO-1 and occludin mRNA. The present study indicates that supplementation with L-carnitine in sows could enhance intestinal barrier integrity by up-regulating the tight junction protein mRNA of newborn and weaning piglets.

DDGS contains approximately three times the amount of most nutrients, such as protein, oil, fibre and minerals, compared with maize ${ }^{(1)}$. Therefore, DDGS is viewed as a potential feed resource to replace a portion of energy (maize) and protein (soyabean meal) ingredients ${ }^{(59)}$. In the past, DDGS had not been used extensively in non-ruminant animal diets because of high fibre content. However, recently, many researchers thought it would be more suitable for sows because of its high content of protein and fat and moderately high fibre content ${ }^{(60)}$. However, there was no study to evaluate the effect of maternal DDGS on intestinal barrier functions of offspring. The present study did not find effects of the DDGS diets of gestating and lactating sows on the intestinal barrier functions of their offspring

The results of the present study indicate that dietary supplementation with L-carnitine in gestating and lactating sows had positive effects on intestinal barrier functions of newborn and weaning piglets. Of note, the positive effects of maternal L-carnitine supplementation did not last to the period of growing-finishing pigs. Within the growing process of offspring, these differences of maternal effects might be subsequently mitigated by the postnatal environment ${ }^{(61)}$

\section{Acknowledgements}

The authors wish to acknowledgement the assistance of Yinguo Li, Chunliang Zhao and Quansheng Liu.

This work was supported by the National Basic Research Program (grant number 2012CB124703), the China Agriculture Research System (grant number CARS-36), the National Science and Technology Support Program (grant number 2013BAD10B03) and the Program for Universities in Heilongjiang province (grant number 2012TD003, 11551z003). The funders had no role in the design, analysis or writing of this manuscript.

All authors participated in the development of the study concept and design; B. W., S. N. and A. S. were responsible for the execution of the study; B. W., S. N. and Z. Q. were involved in the animal experiments, analysis and data collection; Q. M. and Z. C. were responsible for the statistical analysis; B. W. and S. N. wrote the draft of the manuscript; Q. M., A. S. and Z. C. reviewed and revised the manuscript.

None of the authors has any conflicts of interest to declare.

\section{References}

1. Spiehs MJ, Whitney MH \& Shurson GC (2002) Nutrient database for distiller's dried grains with solubles produced from new ethanol plants in Minnesota and South Dakota. J Anim Sci 80, 2639.

2. Song M, Baidoo SK, Shurson GC, et al. (2010) Dietary effects of distillers dried grains with solubles on performance and milk composition of lactating sows. J Anim Sci 88, 3313-3319.

3. Shi Z, Wang L, Su B, et al. (2014) The influence of distillers dried grains with solubles during gestation on sow productivity and milk composition. Ital J Anim Sci 13, 600-603.

4. Wang LS, Su BC, Shi Z, et al. (2013) Dietary supplementation with maize distillers dried grains with solubles during late gestation and lactation: effects on sow and litter performance, and on colostrum and milk composition. Anim Feed Sci Technol 179, 149-153.

5. Song R \& Shurson GC (2013) Evaluation of lipid peroxidation level in corn dried distillers grains with solubles. J Anim Sci 91, 4383-4388.

6. Weber TE \& Kerr BJ (2011) Effect of dietary distillers dried grains with solubles on indicators of oxidative stress and immune function in growing pigs. Livest Sci 142, 85-91.

7. Rebouche CJ (1992) Carnitine function and requirements during the life cycle. FASEB J 6, 3379-3386.

8. Ramanau A, Kluge $\mathrm{H} \&$ Eder K (2005) Effects of L-carnitine supplementation on milk production, litter gains and back-fat thickness in sows with a low energy and protein intake during lactation. Br J Nutr 93, 717-721.

9. Ramanau A, Kluge H, Spilke J, et al. (2004) Supplementation of sows with L-carnitine during pregnancy and lactation improves growth of the piglets during the suckling period through increased milk production. J Nutr 134, 86-92.

10. Musser RE, Goodband RD, Tokach MD, et al. (1999) Effects of L-carnitine fed during gestation and lactation on sow and litter performance. J Anim Sci 77, 3289-3295.

11. Dokmeci D, Akpolat M, Aydogdu N, et al. (2005) L-carnitine inhibits ethanol-induced gastric mucosal injury in rats. Pharmacol Rep 57, 481-488.

12. Akpolat M, Gulle K, Topcu-Tarladacalisir Y, et al. (2013) Protection by L-carnitine against radiation-induced ileal mucosal injury in the rat: pattern of oxidative stress, apoptosis and cytokines. Int J Radiat Biol 89, 732-740.

13. Kalaiselvi T \& Chinnakkannu P (1998) Effect of l-carnitine on the status of lipid peroxidation and antioxidants in aging rats. J Nutr Bio 9, 575-581.

14. Ribas GS, Vargas CR \& Wajner M (2014) L-carnitine supplementation as a potential antioxidant therapy for inherited neurometabolic disorders. Gene 533, 469-476.

15. Akpolat M, Topcu-Tarladacalisir Y, Dokmeci D, et al. (2011) Protective effects of ibuprofen and L-carnitine against whole body gamma irradiation-induced duodenal mucosal injury. Balk Med J 28, 80-85.

16. AOAC (2006) Official Methods of Analysis, 18th ed. Arlington: AOAC.

17. Mao X, Lv M, Yu B, et al. (2014) The effect of dietary tryptophan levels on oxidative stress of liver induced by diquat in weaned piglets. J Anim Sci Biotechnol 5, 49. 
18. Che L, Xuan Y, Hu L, et al. (2015) Effect of postnatal nutrition restriction on the oxidative status of neonates with intrauterine growth restriction in a pig model. Neonatology 107, 93-99.

19. Lee DH, Zo YG \& Kim SJ (1996) Nonradioactive method to study genetic profiles of natural bacterial communities by PCR-single-strand-conformation polymorphism. Appl Environ Microbiol 62, 3112-3120.

20. Walter J, Hertel C, Tannock GW, et al. (2001) Detection of Lactobacillus, Pediococcus, Leuconostoc, and Weissella species in human feces by using group-specific PCR primers and denaturing gradient gel electrophoresis. Appl Environ Microbiol 67, 2578-2585.

21. Heilig HG, Zoetendal EG, Vaughan EE, et al. (2002) Molecular diversity of Lactobacillus spp. and other lactic acid bacteria in the human intestine as determined by specific amplification of 16S ribosomal DNA. Appl Environ Microbiol 68, 114-123.

22. Bartosch S, Fite A, Macfarlane GT, et al. (2004) Characterization of bacterial communities in feces from healthy elderly volunteers and hospitalized elderly patients by using real-time PCR and effects of antibiotic treatment on the fecal microbiota. Appl Environ Microbiol 70, 3575-3581.

23. Rinttila T, Kassinen A, Malinen E, et al. (2004) Development of an extensive set of 16S rDNA-targeted primers for quantification of pathogenic and indigenous bacteria in faecal samples by real-time PCR. J Appl Microbiol 97, 1166-1177.

24. Matsuki T, Watanabe K, Fujimoto J, et al. (2002) Development of $16 \mathrm{~S}$ rRNA-gene-targeted group-specific primers for the detection and identification of predominant bacteria in human feces. Appl Environ Microbiol 68, 5445-5451.

25. Livak KJ \& Schmittgen TD (2001) Analysis of relative gene expression data using real-time quantitative PCR and the 2 (-Delta Delta C(T)) Method. Methods 25, 402-408.

26. Eder K, Ramanau A \& Kluge H (2001) Effect of L-carnitine supplementation on performance parameters in gilts and sows. J Anim Physiol Anim Nutr (Berl) 85, 73-80.

27. Ramanau A, Kluge H, Spilke J, et al. (2002) Reproductive performance of sows supplemented with dietary L-carnitine over three reproductive cycles. Arch Tierernahr 56, 287-296.

28. Ramanau A, Kluge H, Spilke J, et al. (2008) Effects of dietary supplementation of L-carnitine on the reproductive performance of sows in production stocks. Livest Sci 113, 34-42.

29. James BW, Tokach MD, Goodband RD, et al. (2013) Interactive effects of dietary ractopamine $\mathrm{HCl}$ and L-carnitine on finishing pigs: I. Growth performance. J Anim Sci 91, 3265-3271.

30. Rincker MJ, Carter SD, Real DE, et al. (2003) Effects of increasing dietary L-carnitine on growth performance of weanling pigs. J Anim Sci 81, 2259-2269.

31. Birkenfeld C, Ramanau A, Kluge H, et al. (2005) Effect of dietary L-carnitine supplementation on growth performance of piglets from control sows or sows treated with L-carnitine during pregnancy and lactation. J Anim Physiol Anim Nutr 89 , 277-283.

32. Cheung CC, Zheng GJ, Li AM, et al. (2001) Relationships between tissue concentrations of polycyclic aromatic hydrocarbons and antioxidative responses of marine mussels, Perna viridis. Aquat Toxicol 52, 189-203.

33. Szabo S (1984) Role of sulfhydryls and early vascular lesions in gastric mucosal injury. Acta Physiol Hung 64, 203-214.

34. Liu Y, Han J, Huang J, et al. (2009) Dietary L-arginine supplementation improves intestinal function in weaned pigs after an Escherichia coli lipopolysaccharide challenge. Asia Aust J Anim 22, 1667-1675.

35. Cetinkaya A, Bulbuloglu E, Kantarceken B, et al. (2006) Effects of L-carnitine on oxidant/antioxidant status in acetic acidinduced colitis. Dig Dis Sci 51, 488-494.
36. Strzalkowski AK, Godlewski MM, Hallay N, et al. (2007) The effect of supplementing sow with bioactive substances on neonatal small intestinal epithelium. J Physiol Pharmacol 583, $115-122$.

37. Walsh AM, Sweeney T, O'shea CJ, et al. (2013) Effect of dietary laminarin and fucoidan on selected microbiota, intestinal morphology and immune status of the newly weaned pig. Br J Nutr 110, 1630-1638.

38. Liu Y, Huang J, Hou Y, et al. (2008) Dietary arginine supplementation alleviates intestinal mucosal disruption induced by Escherichia coli lipopolysaccharide in weaned pigs. $\mathrm{BrJ}$ Nutr 100, 552-560.

39. Al-Sadi R, Boivin M \& Ma T (2009) Mechanism of cytokine modulation of epithelial tight junction barrier. Front BiosciLandmark 14, 2765-2778.

40. Athanassakis I, Mouratidou M, Sakka P, et al. (2001) L-carnitine modifies the humoral immune response in mice after in vitro or in vivo treatment. Int Immunopharmacol $\mathbf{1}$, 1813-1822.

41. Alesci S, De Martino MU, Mirani M, et al. (2003) L-carnitine: a nutritional modulator of glucocorticoid receptor functions. FASEB J 17, 1553-1555.

42. Abdelrazik H, Sharma R, Mahfouz R, et al. (2009) L-carnitine decreases DNA damage and improves the in vitro blastocyst development rate in mouse embryos. Fertil Steril 91, 589-596.

43. Liu S, Wu H, Zhang Z, et al. (2014) L-carnitine ameliorates cancer cachexia in mice by regulating the expression and activity of carnitine palmityl transferase. Cancer Biol Ther 12, $125-130$.

44. Lahjouji K, Elimrani I, Lafond J, et al. (2004) L-Carnitine transport in human placental brush-border membranes is mediated by the sodium-dependent organic cation transporter OCTN2. Am J Physiol Cell Physiol 287, 263-269.

45. Mathew AG, Upchurch WG \& Chattin SE (1988) Incidence of antibiotic resistance in fecal Escherichia coli isolated from commercial swine farms. J Anim Sci 76, 429-434.

46. Brassart D \& Schiffrin EJ (1997) The use of probiotics to reinforce mucosal defence mechanisms. Trends Food Sci Technol 8, 321-326.

47. Brown K, Decoffe D, Molcan E, et al. (2012) Diet-induced dysbiosis of the intestinal microbiota and the effects on immunity and disease. Nutrients $\mathbf{4}, 1095-1119$.

48. Wang H, Zhang W, Zuo L, et al. (2013) Bifidobacteria may be beneficial to intestinal microbiota and reduction of bacterial translocation in mice following ischaemia and reperfusion injury. Br J Nutr 109, 1990-1998.

49. Anderson RC, Cookson AL, McNabb WC, et al. (2010) Lactobacillus plantarum MB452 enhances the function of the intestinal barrier by increasing the expression levels of genes involved in tight junction formation. BMC Microbiol 10, 316 .

50. Atarashi K, Tanoue $\mathrm{T}$, Shima $\mathrm{T}$, et al. (2011) Induction of colonic regulatory $\mathrm{T}$ cells by indigenous clostridium species. Science 331, 337-341.

51. Bauer E, Williams BA, Smidt $\mathrm{H}$, et al. (2006) Influence of dietary components on development of the microbiota in single-stomached species. Nutr Res Rev 19, 63-78.

52. De Filippo C, Cavalieri DD, Paola M, et al. (2010) Impact of diet in shaping gut microbiota revealed by a comparative study in children from Europe and rural Africa. Proc Natl Acad Sci USA 107, 14691-14696.

53. Birkenfeld C, Doberenz J, Kluge H, et al. (2006) Effect of l-carnitine supplementation of sows on l-carnitine status, body composition and concentrations of lipids in liver and plasma of their piglets at birth and during the suckling period. Anim Feed Sci Technol 129, 23-38. 
54. Rist VT, Eklund M, Bauer E, et al. (2012) Effect of feeding level on the composition of the intestinal microbiota in weaned piglets. J Anim Sci 90, Suppl. 4, 19-21.

55. Ulluwishewa D, Anderson RC, McNabb WC, et al. (2011) Regulation of tight junction permeability by intestinal bacteria and dietary components. J Nutr 141, 769-776.

56. Zhong Y, Cai D, Cai W, et al. (2009) Protective effect of galactooligosaccharide-supplemented enteral nutrition on intestinal barrier function in rats with severe acute pancreatitis. Clin Nutr 28, 575-580.

57. Chen H, Mao X, He J, et al. (2013) Dietary fibre affects intestinal mucosal barrier function and regulates intestinal bacteria in weaning piglets. Br $J$ Nutr 110, 1837-1848.

58. Berin MC, Yang PC, Ciok L, et al. (1999) Role for IL-4 in macromolecular transport across human intestinal epithelium. Am J Physiol 276, 1046-1052.
59. Wang H, Wang LS, Shi BM, et al. (2012) Effects of dietary corn dried distillers grains with solubles and vitamin $\mathrm{E}$ on growth performance, meat quality, fatty acid profiles, and pork shelf life of finishing pigs. Livest Sci 149, 155-166.

60. Li X, Baidoo SK, Li YZ, et al. (2014) Interactive effects of distillers dried grains with solubles and housing system on reproductive performance and longevity of sows over three reproductive cycles. J Anim Sci 92, 1562-1573.

61. Kunz LH \& King JC (2007) Impact of maternal nutrition and metabolism on health of the offspring. Semin Fetal Neonatal Med 12, 71-77.

62. National Research Council (1998) Nutrient Requirements of Swine, 10th ed. Washington, DC: National Academy of Science.

63. Xiong BH, Pang ZH \& Luo QY (2008) Tables of feed composition and nutritive values in China. Chin Feed 21-22, $35-41 / 28-37$. 